\title{
Vegetation Structure And Carbon Stock In The Mangrove Community Of Payumb Coast, Merauke Regency, Papua
}

\author{
Reny Sianturi ${ }^{1 *}$, Devi N. Choesin ${ }^{2}$ \\ ${ }^{1}$ Department of Aquatic Resources Management, Musamus University, Jalan Kamizaun Mopah Lama, Merauke-Papua \\ ${ }^{2}$ Department of Biology, School of Life Sciences and Technology, Bandung Institute of Technology, Jalan Ganesha 10, \\ Bandung 40132, West Java- Indonesia
}

\begin{abstract}
Mangrove forests in Indonesia play an important role in mitigating climate changes and providing other ecosystem services; however, their extent continues to decline. Information on mangrove community and its carbon stock, especially for Papua, is still limited. This study was conducted to describe vegetation structure and estimate carbon stock in Payumb Coast in Merauke District, Papua. There were three primary mangrove species identified, namely, Avicennia alba, Rhizophora apiculata and Sonneratia alba. Species dominance varied along a gradient of salinity and substrate perpendicular to the shoreline. A. alba is dominant in the closest zone to the shoreline (importance value 205.76\%), while $R$. apiculata is dominant in the farthest zone (importance value 185,35). At the community level, the carbon stock in trees differed significantly between zones $(\mathrm{p}<0.05)$, with the highest in the zone dominated by $R$. apiculata. This study has provided preliminary data on carbon stock estimation at the community level; further studies should be conducted to estimate total carbon stock based on all above- and belowground components. More accurate estimations become important, as it was found that different species could contain significantly different carbon stock; thus producing variation among mangrove communities.
\end{abstract}

Keywords: mangrove, carbon stock, Merauke, Payumb, climate change

\section{Introduction}

Indonesia has $81.000 \mathrm{~km}$ of coastline with the largest mangrove forest area in the world (Hartomo, 2004) [10]. However, the extent of mangrove forest in Indonesia continues to decline caused by various human activities. The problems also arise due to climate change trends that threaten the existence of forests in coastal areas, especially for mangrove forests, and potentially cause the mangrove areas to continuously decline. Though the ecosystem plays a role in climate change mitigation because of its ability to absorb $\mathrm{CO}_{2}$ from the atmosphere, the high level of threats to mangrove forests, there is a need to make efforts to improve the role of mangrove forests as carbon sinks from the environment.

There have been several research conducted on the calculation of carbon stock in mangrove forest area, among others, Wang (2013) in Yingluo Bay region, South China; Sitoe et al. (2014) in Mozambique; and Wulansari (2009) mangrove forests in Pulau Dua, Banten [21, 19, 23]. However, there is a need of more research conducted to compare different mangrove communities, especially for Indonesia.

The largest mangrove forest in Indonesia is in Papua Province, with an area of 1,3 million hectares (Santoso et al., 2005) [17]; however, the information on the community structure and carbon stock of mangroves in the region is still limited. One example of mangrove forest is on Payumb Coast, Merauke
Regency, which is a regency in the southern part of Papua with a mangrove forest area of 4.672,382 hectares (BAPPEDA of Merauke Regency, 2008) [2]. Some of the researches conducted previously at Payumb Coast were conducted by Monika (2012) on macrozoobenthos community structure in mangrove ecosystems, and by Kustyarini and Djaja (2011) on bivalve diversity $[15,14]$. However, there have not been special research on vegetation structure and carbon stock in the mangrove community conducted.

The purpose of this research is to study mangrove community in Payumb Coastal area, Merauke regency, Papua province, so that it is able to collect the following information; (1) structure of mangrove vegetation and its zonation illustration; (2) carbon stocks at the community level; and (3) comparison of carbon stocks in different mangrove species. The results of this study are expected to be the basis of information for the community and local government for further management and research in the future for developing lowcarbon society.

\section{Research Method}

This study was conducted in the mangrove forest area at Payumb beach, Merauke Regency, Papua province (Fig 1). Geographically, Merauke Regency is located on $5^{\circ}-9^{\circ}$ South and $137^{\circ}-141^{\circ}$ East. Field data 
were collected from June to September 2014, followed by sample processing and data analysis. The two main stages of the research were (1) analysis of vegetation structure; and (2) estimation of carbon stock. The analysis of vegetation structure included vegetation description and determination of regeneration potential of each species; while carbon stock estimation was conducted by looking at two aspects, namely, carbon stocks of trees at the community level, and carbon stocks of trees and staples at the species level to compare different types.

Fig 1. Location Of Research And Placement Of Sampling Transect.

\subsection{Vegetation Structure Analysis}

Data collection to describe vegetation and determine the potential for regeneration was done by using line transect method that was put parallel to the coastline (Fig. 1). Three transects were expected to show three different zones: zone A (near the shoreline), zone B (center) and zone C (far away from the shoreline). The length of each transect is $60 \mathrm{~m}$, with a distance between transects of $20 \mathrm{~m}$. In each transect, a sample plot of $10 \times 10 \mathrm{~m}^{2}$ was put for trees, $5 \times 5 \mathrm{~m}^{2}$ for staples, and $1 \times 1 \mathrm{~m}^{2}$ for seeds, each with three repetitions along the transects.

Data recorded on each sample plot were plant species, number of individuals, and stem diameter at breast height or DBH for trees and staples (Cintron and Schaeffer Novelli, 1984; English et al., 1994) [6-7]. Plant categories were as follows: tree level if the DBH $\geq 5 \mathrm{~cm}$; staple level if the height $<1,5 \mathrm{~m}$ and $\mathrm{DBH}<$ $5 \mathrm{~cm}$; seed level if the height is $10 \mathrm{~cm}<1.5 \mathrm{~m}$ (Sherman et al., 2000) [18]. The DBH values obtained were then used in the calculation of mastery of the stem against the surface of the substrate or basal area $(\mathrm{LAB})$ as follows: $\mathrm{LAB}=\mathrm{LAB}=л \times \mathrm{DBH}^{2} / 4$.

\subsubsection{Description of vegetation}

Vegetation data were processed in order to obtain an important value index (INP) of each plant species encountered. INP was obtained from the calculations of relative frequency, relative density, and relative thickness (Bengen, 2002) [3]. The calculation of INP was performed using the following ways:

The relative frequency value of a species (Fr) was obtained by using the following formula:

$$
\mathrm{Fr}=\frac{\text { Frekuensi jenis }}{\text { Frekuensi total }} \times 100 \%
$$

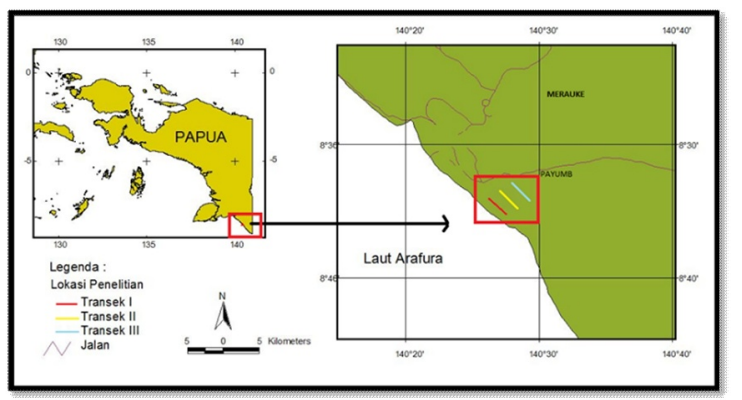

The relative density value of a species $(\mathrm{Kr})$ was obtained by using the following formula:

$$
\mathrm{Kr}=\frac{\text { Kerapatan jenis }}{\text { Kerapatan total }} \times 100 \%
$$

The relative $\mathrm{LAB}$ value of a species (Kbr) was obtained by using the following formula:

$$
\text { LAB relatif }=\frac{\text { LAB jenis }}{\text { LAB total }} \times 100 \%
$$

From the calculation results, the INP of a species was obtained by using the following formula:

Important Value Index $(\mathrm{INP})=\mathrm{Fr}+\mathrm{Kr}+\mathrm{Kbr}$

In order to obtain the overview of the relationship between vegetation and abiotic environmental factors, a physical-chemical factor measurement was performed, including salinity, soil texture, soil organic content, soil $\mathrm{pH}$, and air temperature,

\subsubsection{Carbon Stock Estimation}

The data needed to calculate the carbon stock at the community level were all DBH data of all the trees encountered. The data were similar to the data collected for vegetation analysis using the transect method and the $10 \times 10 \mathrm{~m}^{2}$ sample plot. Data for estimating and comparing carbon stocks between mangrove species were obtained from different sample plots of vegetation analysis; referring to the method developed by Hariah and Rahayu (2007) [9]. Measurement of trees and staples to estimate carbon stock was carried out in the sample plots with nested plot. Three sample plots were made in zone A, B, and C. The $20 \times 10 \mathrm{~m}^{2}$ plot was used for extracting the tree life and $10 \times 5 \mathrm{~m}^{2}$ plots for the level of life of staples. The criteria of trees and staples are as previously described. DBH measurements of trees and staples were carried out to estimate the biomass and, subsequently, carbon stock. Biomass analysis was performed using Allometric equation by entering the $\mathrm{DBH}$ data, then carbon content was estimated from biomass by using conversion ratio of $50 \%$ of total biomass. The equation for the calculation of mangrove biomass is different from other plant species. The Allometric equation for estimation of mangrove biomass (Komiyama et al., 2008) [12] is as follow: Biomass : $0,251 \rho \mathrm{D}^{2,46}$, where; $\mathrm{D}=$ diameter; $\rho=$ specific gravity of wood $\left(\mathrm{g} / \mathrm{cm}^{3}\right)$.

\section{Results}

\subsection{Vegetation Structure Analysis}

\subsubsection{Description of Vegetation}

Based on the results of field observation, that sandy clay and clay-sand textures are the dominant substrates in Payumb beach, with a salinity range between 29-39 ppt. A. alba has a sandy substrate preference with a low concentration of clay to grow, whereas $S$. alba and $R$. apiculata have the same substrate preferences, clay with a low concentration of sand. 


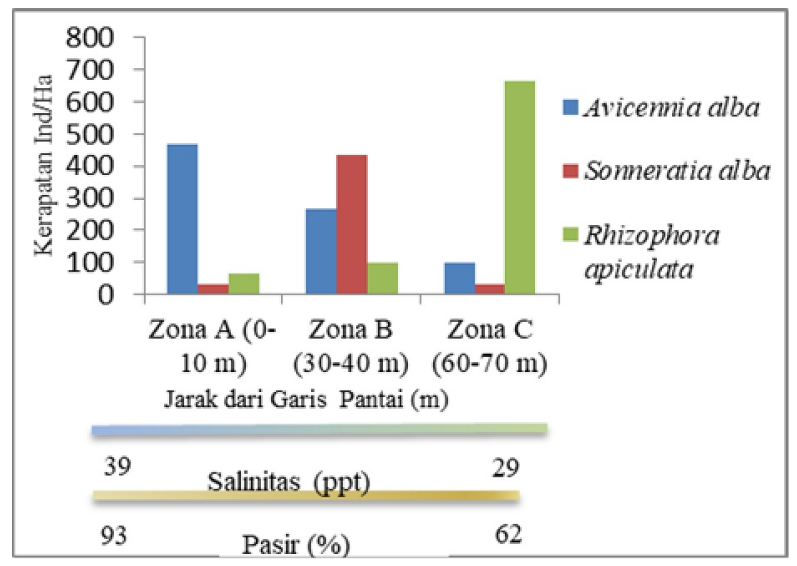

Fig. 2. The Distribution Of Mangrove Along The Salinity Gradient And Soil Texture

The distribution of mangroves at the Payumb Coast as the observation site, as seen from the zonation formed along the salinity gradient and substrate texture, is shown in Fig. 2. In accordance with the INP calculation, in zone A (range $0-10 \mathrm{~m}$ ), it is seen that the very prominent mangrove density is $A$ alba. Meanwhile, $S$. alba showed a prominent density in zone B (at a distance of 30-40 m), followed by A. alba. Both of these species become codominant on the zone. Furthermore, $R$. apiculata is found with a prominent density in zone $\mathrm{C}$ (at a distance of 60-70 m).

\subsection{Carbon Stock Animation}

\subsubsection{Carbon Stock of Trees at the Community Level}

From the analysis of vegetation structure, there are three mangrove zones, namely zone A, which is dominated by Avicennia alba mangrove, Zone B is dominated by Avicennia alba and Sonneratia alba while $\mathrm{C}$ zone is dominated by Rhizophora apiculata mangrove species. These three zones were each calculated for their total carbon stock at the level of life of trees.

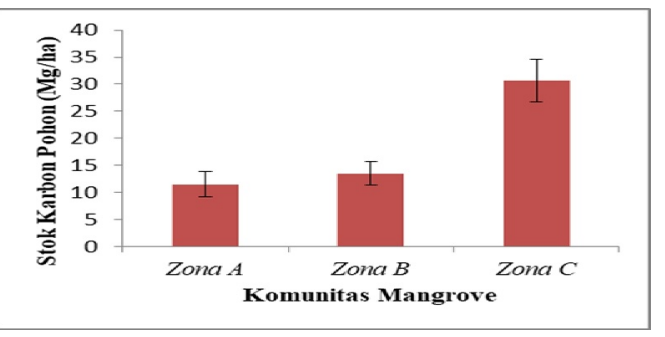

Fig. 3. Carbon Stocks Of Trees In Zone A, B And C

The estimation of carbon stocks between the mangrove communities in zone $\mathrm{A}, \mathrm{B}$ and $\mathrm{C}$ is 11,53 $\mathrm{Mg} / \mathrm{ha}, 13,53 \mathrm{Mg} / \mathrm{ha}$ and $30,65 \mathrm{Mg} / \mathrm{ha}$, respectively (Fig 3). The diameter of trees encountered on the Payumb coast is relatively small with an average size of $10,39 \mathrm{~cm}$.

\subsubsection{The Comparison of Carbon Stocks between Mangrove Species}

The value of carbon stocks of A. alba, S. alba and $R$. apiculata is $24,27 \mathrm{~kg} /$ tree, $18,65 \mathrm{~kg} /$ tree and $39,37 \mathrm{~kg} /$ tree, respectively (Fig. 4). The size of the tree and the density of $R$. apiculata are highest compared to the other species.

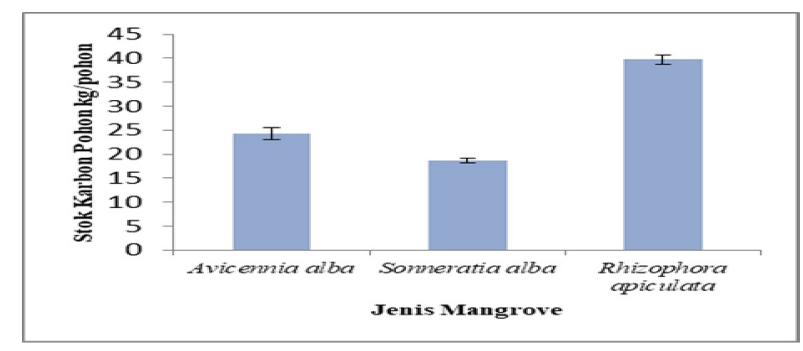

Fig. 4. Comparison Of Tree Carbon Stock On Different Magrove Species

Based on ANOVA test results, the carbon stock value, in general, is significantly different $(\mathrm{P}<0,05)$ between zones, except between zone $\mathrm{A}$ and $\mathrm{B}(\mathrm{P}>0,05)$. The density value of trees in zone A, B and $\mathrm{C}$ is 566,67 $\mathrm{ind} / \mathrm{ha}, 800 \mathrm{ind} / \mathrm{ha}$ and $800 \mathrm{ind} / \mathrm{ha}$, respectively. The value of carbon stocks increases along with the increasing density of trees in zone A, B and C.

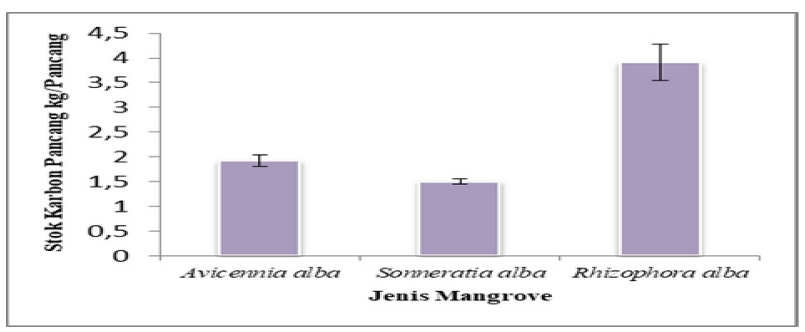

Fig. 5. Comparison Of Staple Carbon Stock On Differen Magrove Species.

At the staple level, the estimated carbon stock of A. alba, $S$. alba and $R$. apiculata is $1,92 \mathrm{~kg} / \mathrm{staple}, 1,50$ $\mathrm{kg} /$ staple and 3,91 kg/staple, respectively (Fig. 5). Based on the ANOVA test, there is no significant difference in the carbon stock value between $A$. alba and $S$. alba species, but there is a significant difference in carbon stock value of $R$. apiculata $(\mathrm{P}<0,05)$.

\section{Discussion}

Based on vegetation analysis, the number of mangrove species found in Payumb Coast is less than other mangrove areas in Papua, for example, in Bintuni Bay in which there are 11 mangrove species found (Kusmana, 2003) [13]. In West Papua, the mangrove area in Wondama Bay is also recorded to have 11 species (Auri, 2009) [1]. Overall, Avicennia alba has the highest Importance Value Index (INP) compared to other types, which is $205,76 \%$. The dominance of $A$. alba in zone A which is near the coastline can be due 
to its adaptability to the sea waves and the survival ability up to the level of trees compared to other mangrove species. Sonneratia alba and Avicennia alba that grow with the highest INP in Zone B, which is farther away from the coastline, are able to live within a nearly equal salinity range of $30 \mathrm{ppt}$ to $39 \mathrm{ppt}$ (Bengen and Dutton, 2004) [4]. Zone C is dominated by Rhizophora apiculata. In general, this species grows in sandy clay textures that have relatively high levels of organic material with salinity in the range of 10-30 ppt (Bengen and Dutton, 2004) [4], according to conditions in Zone $\mathrm{C}$ transect that have sandy clay texture.

A. alba has a sandy substrate preference with a low concentration of clay to grow, whereas $S$. alba and $R$. apiculata have the same substrate preferences, clay with a low concentration of sand. This is supported by field observations that found that it has sandy clay texture. A. alba, S. alba and R. apiculata are pioneer mangrove species. The sandy substrate is perfect for pioneer mangroves. However, only A. alba lives on the sandy substrate at Payumb Coast. $S$. alba and $R$. apiculata have a preference for clay substrate with a low concentration of sand. The substrate preference shown by $R$. apiculata is in accordance with the research conducted by Kusmana (2003) [13] which states that this type generally lives on the clay substrate.

In general, the three main mangrove species in Payumb beach, namely $A$. alba, $S$. alba and $R$. apiculata, have good regeneration potential. It is suspected that Payumb Coast have resources such as soil, nutrients, and sufficient light for the living places of these three species. The potential for regeneration is determined by the biological factors of reproduction originating within the plant itself and the environmental factors of living place (Rasnovi, 2006) [16].

The estimation of carbon stocks in the mangrove community in zone $\mathrm{A}, \mathrm{B}$ and $\mathrm{C}$ is 11,53 $\mathrm{Mg} / \mathrm{ha}, 13,53 \mathrm{Mg} / \mathrm{ha}$ nad $30,65 \mathrm{Mg} / \mathrm{ha}$, respectively. According to data obtained by Taberima et al. (2014) [20], the carbon stock of trees in the mangrove ecosystems in Bintuni, Teminabuan and Timika Papua is $212,12 \mathrm{Mg} / \mathrm{ha}, 219,24 \mathrm{Mg} / \mathrm{ha}$ and $139,89 \mathrm{Mg} / \mathrm{ha}$, respectively. Thus, the value of carbon stocks in Payum Coast, Merauke Regency, is much lower. This difference is thought to be affected by tree size. Gorte (2007) [8] states that tree biomass will depend on some factors including: tree density, variation of plant species, tree size, and environmental factors. In addition, differences in tree diameter also have an effect on the differences in carbon stock in mangrove species. In this case, the average diameter of trees found on Payumb Coast is 9,38, much lower than the diameter of the mangrove trees in Bintuni, Teminabuan and Timika, Papua with an average of $30 \mathrm{~cm}$. The estimated carbon stock at Payumb Coast is closer to the value reported by Sitoe et al. (2014) [19] for a mangrove forest in Sofala Bay, Mozambique, where the total carbon of above-ground reaches only 33,3 $\mathrm{Mg} / \mathrm{ha}$.
The tree carbon stock value in $A$. alba, S. alba and $R$. apiculata is $24,27 \mathrm{~kg} /$ tree, $18,65 \mathrm{~kg} /$ tree and $39,37 \mathrm{~kg} /$ tree, respectively. Chave et al. (2005) [5] states that the estimation of above ground biomass, especially for tree, are related to tree diameter, specific gravity and tree height. In this study, the measurement of allometric equations was conducted by using tree diameter so that differences in the amount of carbon stocks in trees can be attributed to differences in tree size. The diameter of $R$. apiculata is larger than the other. The diameter value of each species has a great effect on the estimation of biomass and carbon stock.

The carbon stock value of staple on $A$. alba, $S$. alba and $R$. apiculata species is 1,92 kg/staple, 1,50 $\mathrm{kg} /$ staple and $3,91 \mathrm{~kg} /$ staple, respectively. According to Widyastuti (2005) [22], carbon stock will increase as the trunk diameter increases. The staple has a smaller diameter than the tree, so that the carbon stock in the staple is smaller. Based on the ANOVA test, the carbon stock value on mangrove species is not significantly different $(\mathrm{P}>0,05)$ between $A$. alba and $S$. alba. A. alba has a higher carbon stock than that of S. alba. A. alba has a higher tolerance to salinity than the $S$. alba that has an effect on biomass, as well as the absorbed carbon. The obvious difference was shown in the $R$. apiculata $(\mathrm{P}<0,05)$. This is thought to be related to the weight of the tree species. In this study, the specific gravity of tree species is a biomass calculation variable used in the allometric equation to determine the carbon stock of trees and staples. The influencing factors on the specific gravity of tree species include leaf weight, root weight and wood density (Komiyama, 2005) [11]. The morphology and structure of $R$. apiculata are different because they have leaves and stilt roots, so that $R$. apiculata has greatest specific gravity than other species. The greater the specific gravity of a tree, the greater the biomass and the carbon stock.

In general, it can be concluded that the mangrove vegetation at Payumb Coast, Merauke, consists of pioneer species. As a preliminary overview, there have been estimation of carbon stocks for trees obtained at the community level; however, further research needs to be done on the overall carbon stock covering the soil and other components in order to obtain a more accurate estimation of the potential of the carbon stock on the site. This estimation becomes important once it is recognized that different plant species can contain significantly different carbon stocks, so that the carbon stocks in various mangrove communities cannot be considered the same.

\section{Acknowledgement}

The authors would like to thank the manager of SITH-ITB facilities, especially for the Terrestrial and Terrestrial Ecosystem Analysis Bandungense Laboratory; the community and head of Payumb village, Merauke; as well as all those who have assisted in collecting the field data and providing laboratory and analysis facilities. 


\section{References}

1. Auri, Y.F.A. 2009. Analisis Vegetasi Mangrove dan Pemanfaatannya oleh Masyarakat Kampung Isenebuai, Distrik Rumberpon, Kabupaten Teluk Wondama. Skripsi Jurusan Biologi FMIPA, Universitas Negeri Papua, Manokwari.

2. Badan Perencanaan Pembangunan Daerah (BAPPEDA). 2008. Papua Dalam Angka. Provinsi Papua.

3. Bengen. 2002. Ekosistem dan Sumberdaya Alam Pesisir. Pusat Kajian Sumberdaya Pesisir dan Lautan. Sipnosis. Institut Pertanian Bogor. Bogor.

4. Bengen. D. G. dan I. M. Dutton 2004. Interaction: Mangroves, Fisheries and Forestry Management In Indonesia. H. 632-653. Dalam Northcote. T. G. dan Hartman (Ed), Worldwide watershed interaction and management. Blackwell science.. Oxford. UK.

5. Chave, J., Andalo, C., Brown, S., Cairns, M.A., Chambers, J.Q., Eamus, D., Fölster, H.,Fromard, F., Higuchi, N., Kira, T., Lescure, J.P., Nelson, B.W., Ogawa, H., Riéra,H.P.B., Yamakura, T., 2005. Tree Allometry and Improved Estimation of Carbonstocks and Balance In Tropical Forests. Oecologia 145, 8799.

6. Cintrón, G. dan Schaeffer-Novelli, Y., 1984. Methods for Studying Mangrove Structure. Dalam: S.C. Snedaker dan J.G. Snedaker, The mangrove ecosystem: research methods. UNESCO, Bungay, United Kingdom.

7. English, S., Wilkinson, C., and Baker, V. 1994. Survey Manual for Tropical Marine Resources. Townsville: Australian Institute of Marine Science.

8. Gorte, R. W. 2007. CRS report RI 31432: Carbon Sequestration in Forest. Congressional Research Service.

9. Hairiah, K. dan Rahayu, S. 2007. Pengukuran 'Karbon Tersimpan' di Berbagai Macam Penggunaan Lahan. World Agroforestry Centre. ICRAF, SEA Regional Office, University of Brawijaya, Indonesia.

10. Hartomo, W. 2004. Perencanaan Pengelolaan Sumberdaya Pesisir Secara Terpadu Dalam Menunjang Pembangunan Daerah. Pengantar ke Falsafah Sains (PPO72), Sekolah Pasca Sarjana/S3. Bogor: Institut Teknologi Bogor.

11. Komiyama, A., S. Poungparn and S. Kato. 2005. Common Allometric Equation For Estimating The Tree Weight Of Mangroves. Journal of Tropical Ecology, 21: 471-477.
12. Komiyama, A., J.E. Ong and S. Poungparn. 2008. Allometry, Biomass, and Productivity of Mangrove Forests: a review. Aquatic Botany, 89: 128 - 137.

13. Kusmana, C., Onrizal, Sudarmadji. 2003. JenisJenis Pohon Mangrove di Teluk Bintuni, Papua. Bogor: Fakultas Kehutanan IPB dan PT BUMWI.

14. Kustyarini, L dan Djaja, I. 2011. Keanekaragaman Bivalvia Di Pesisir Pantai Payumb Kelurahan Samkai Distrik Merauke. Skripsi Sarjana Manajemen Sumberdaya Perairan. UNMUS, Merauke.

15. Monika, N.S. 2013. Struktur Komunitas Makrozoobentos Pada Ekosistem Mangrove Di Pesisir Distrik Merauke, Kabupaten Merauke. Tesis Pascasarjana Pengelolaan Lingkungan Hidup. Unhas, Makassar.

16. Rasnovi, S. 2006. Ekologi Regenerasi Tumbuhan Berkayu Pada Sistem Agroforest Karet. Pascasarjana Ilmu Kehutanan. IPB, Bogor.

17. Santoso, N., Bayu, C.N., Ahmad, F.S, dan Ida, F. 2005. Resep Makanan Berbahan Baku Mangrove dan Pemanfaatan Nipah. Lembaga Pengembangan dan Pengkajian Mangrove.

18. Sherman, R. E, Jahey, T.J, Battle, J.J. 2000. Small-scale Disturbance and Regeneration Dynamics in a Neotropical Mangrove Forest. Journal of ecology. 88:165-178.

19. Sitoe, A.A., L.J.C. Mandlate and B.S. Guedes. 2014. Biomass and Carbon Stocks of Sofala Bay Mangrove Forests. Forests 5: 1967-1981; doi:10.3390/f5081967

20. Taberima, S., Nugroho, Y. D., dan Murdiyarso, D. 2014. The Distribution of Carbon Stock in Selected Mangrove Ecosystem of Wetlands Papua: Bintuni, Teminabuan, and Timika Eastern Indonesia. International Conference on Chemical, Environment \& Biological Sciences (CEBS-2014) Sept. 17-18.

21. Wang, G., Guan, D., Peart, M. R., Chen, Y., dan Peng, Y. 2013. Ecosystem carbon stocks of mangrove forest in Yingluo Bay, Guangdong Province of South China. Articel.

22. Widyastuti, H. 2005. Estimasi Stok Karbon pada Hutan Pinus Berbagai Umur di Kawasan Gunung Tangkubanparahu, Jawa Barat. Skripsi Sarjana Biologi. ITB, Bandung.

23. Wulansari, M. 2009. Perbandingan Stok Karbon pada Hutan Mangrove dan Non Mangrove di Pulau Dua Banten. Skripsi Sarjana Biologi. Institut Teknologi Bandung, Bandung. 